\title{
Erratum to: Estimates of vital rates for a declining loggerhead turtle (Caretta caretta) subpopulation: implications for management
}

\author{
Margaret M. Lamont • I. Fujisaki · Raymond R. Carthy
}

Published online: 9 January 2015

(C) Springer-Verlag Berlin Heidelberg 2015

\section{Erratum to: Mar Biol (2014) 161:2659-2668 \\ DOI 10.1007/s00227-014-2537-0}

The Open Robust Model methods used for analysis in this study were developed by Kendall and Bjorkland (2001) and Kendall (2010). The language used in this manuscript to describe formatting and implementation of data for these analyses was derived heavily from Phillips et al. (2014). Therefore, the wording in the last paragraph of the 'Materials and methods' (p. 2662) and in the last paragraph of the 'Results' (p. 2663) of our publication is largely identical to the corresponding sections on pp. 865-866 in Phillips et al. (2014). Unfortunately, we did not indicate this adequately, thus proper credit was not given to the contribution of Phillips et al. (2014) in our publication.

Communicated by U. Sommer.

The online version of the original article can be found under doi:10.1007/s00227-014-2537-0.

M. M. Lamont $(\bowtie)$

Southeast Ecological Science Center, US Geological Survey

(USGS), Gainesville, FL, USA

e-mail: mlamont@usgs.gov

I. Fujisaki

Department of Wildlife Ecology and Conservation,

Ft. Lauderdale Research and Education Center, Davie, FL, USA

R. R. Carthy

Florida Cooperative Fish and Wildlife Research Unit, Department of Wildlife Ecology and Conservation, US Geological Survey,

University of Florida, Gainesville, FL, USA

\section{References}

Kendall WL (2010) The 'robust design'. In: Cooch E, White GC (eds) Program MARK: a gentle introduction, pp 15/1-15/50. http:// www.phidot.org/software/mark/docs/book

Kendall WL, Bjorkland R (2001) Using open robust design models to estimate temporary migration from capture-recapture data. Biometrics 57:1113-1122

Phillips KF, Mansfield KL, Die DJ, Addison DS (2014) Survival and remigration probabilities for loggerhead turtles (Caretta caretta) nesting in the Eastern Gulf of Mexico. Mar Biol 161:863-870. doi:10.1007/s00227-013-2386-2 